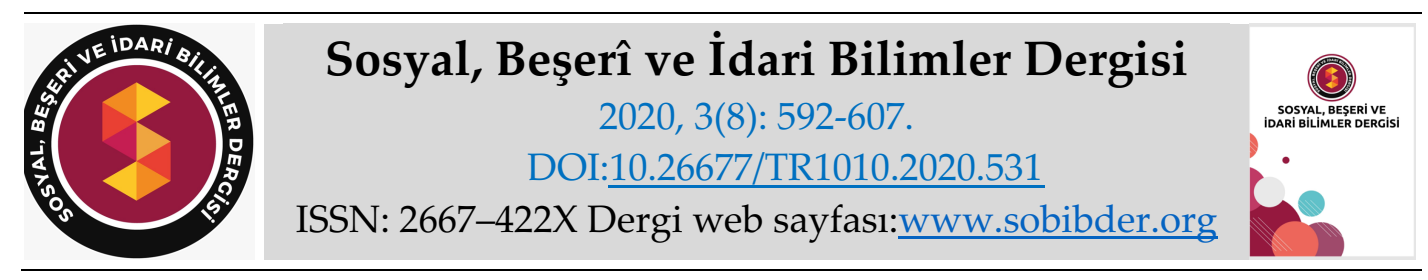

ARASTTIRMA MAKALESI

\title{
Uluslararası Yatırım Pozisyonunun Varlıklar ve Yükümlülükler Kalemleri ile VIX Korku Endeksi Arasındaki İlişki: Türkiye Örneği
}

Sina MEHRANG, Doktora Öğrencisi, Gazi Üniversitesi, Sosyal Bilimler Enstitüsü, Ankara, e-posta: Sinamehrang@gmail.com

ORCID: https://orcid.org/0000-0001-6374-8014

Öz

Son dönemlerde önemini daha arttırarak uluslararası yatırım pozisyonu ile finansal piyasalarda Küresel risk iştahının göstergesi olarak kabul edilen VIX (volatility index) endeksi birçok ülkenin finansal yapıcıları tarafından mercek altına alınmıştır. Çalışmanın amacı uluslararası yatırım pozisyonun (UYP) varlıklar ve yükümlülükler kalemleri ile opsiyon fiyatlarında ileriye dönük risk beklentilerini yansıtan zımni bir risk ölçümü olan Chicago Opsiyon Borsası tarafından hesaplanan VIX korku endeksi arasındaki ilişkiyi hata düzeltme modeli, ARDL eşbütünleşme testi ve Granger nedensellik analizi ile belirlemektir. Çalışma Türkiye için 2006 ile 2019 yılları arasında çeyreklik verileri kullanarak yapılmıştır. Eşbütünleşme testi sonucuna göre VIX endeksi ile UYP varlık ve yükümlülük kalemleri arasında uzun dönem de negatif yönlü bir ilişki olduğu tespit edilmiştir. Hata düzeltme modeline dayanan bulgulara göre uzun döneme uyumlu bir şekilde varlık ve yükümlülük kalemleri ile VIX endeksi arasında kısa dönem 'de negatif yönlü bir ilişki mevcuttur. Granger nedensellik ilişkisi açısından sadece VIX endeksinden varlık kalemine doğru tek taraflı bir nedensellik ilişki sonucuna varılmıştır.

Anahtar Kelimeler: Uluslararası Yatırım Pozisyonu, Varlıklar, Yükümlülükler, VIX Korku Endeksi.

Makale Gönderme Tarihi: 15.03 .2020

Makale Kabul Tarihi: 02.08 .2020

\section{Önerilen Atıf:}

Mehrang, S. (2020). Uluslararası Yatırım Pozisyonunun Varlıklar ve Yükümlülükler Kalemleri ile VIX Korku Endeksi Arasındaki İlişki: Türkiye Örneği, Sosyal, Beşeri ve İdari Bilimler Dergisi, 3(8): 592-607.

C 2020 Sosyal, Beşerî ve İdari Bilimler Dergisi. 


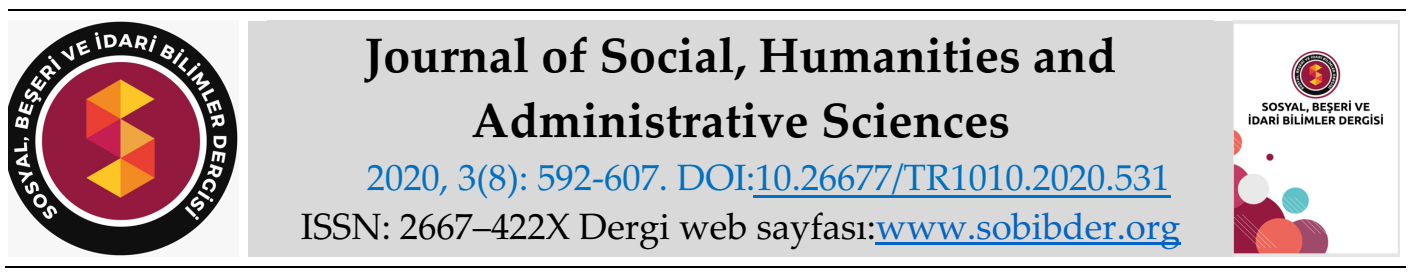

\title{
$\underline{\text { RESEARCH PAPER }}$
}

\section{The Relationship between International Investment Position's Assets and Liabilities Items with the VIX Fear Index: The Case of Turkey}

Sina MEHRANG, Ph.D. Student, Gazi University, Social Sciences Institute, Ankara, e-mail: Sinamehrang@gmail.com

ORCID: https://orcid.org/0000-0001-6374-8014

\begin{abstract}
The VIX (volatility index), that has recently become more important as an indicator of the global risk appetite in the financial markets with its international investment position, has been scrutinized by the financial makers of many countries. The aim of the study is to determine the relationship between the assets and liabilities items of the international investment position (UYP) and the VIX fear index calculated by the Chicago Option Exchange, which is an implicit risk measure that reflects the prospective risk expectations in option prices, with error correction model, ARDL cointegration test and Granger causality analysis. The study was conducted using quarterly data for Turkey between 2006 and 2019. According to the cointegration test results, a long-term negative relationship was found between the VIX index and the UYP asset and liability items. According to the findings based on the error correction model, there is a negative relationship between the asset and liability items and the VIX index in a short term in accordance with the long term. In terms of the Granger causality relationship, only one-sided causality relationship has been reached from the VIX index to the asset item.
\end{abstract}

Keywords: International Investment Position, Assets, Liabilities, VIX Fear Index.

Received: 15.03 .2020

Accepted: 02.08.2020

\section{Suggested Citation:}

Mehrang, S. (2020). The Relationship between International Investment Position's Assets and Liabilities Items with the VIX Fear Index: The Case of Turkey, Journal of Social, Humanities and Administrative Sciences, 3(8): 592-607.

(c) 2020 Sosyal, Beşerî ve İdari Bilimler Dergisi. 


\section{Gíriş}

Teknolojik gelişmeler sayesinde bilginin hızlı dolaşımı, finansal serbestleşme ve uluslararası sermaye akımlarının kolaylıkla gerçekleşmesi farklı ülkelerdeki finansal piyasaların birbirine entegrasyonunu beraberinde sağlamıştır. Finansal entegrasyonun bir sonucu olarak herhangi bir piyasada meydana gelen gelişmelerden diğer piyasaların da etkilenmemesi kaçınılmaz hale gelmiştir. Piyasalar arasındaki yüksek bağlantı finansal uygulayıcıları ve karar mekanizmalarını dünyadaki ekonomik gelişmeler, finansal piyasalarda meydana gelen krizler, siyasi belirsizlikler gibi gelişmeleri göz önünde bulundurma önemini daha da artmıştır.

Artan küreselleşme ile beraber birbirine entegre olan finansal piyasalardaki meydana gelen volatilite diğer finansal piyasaları da kısa bir surede etkilemektedir. Nitekim 2008 yılında Amerika Bileşik Devletleri'nde ortaya çıkan kriz eş zamanlı olarak finansal bütünleşme içerisinde bulunan tüm ülkeleri dolaylı ve dolaysız olarak etkilemiş ve Küresel Finans Krizi haline gelmiştir. $\mathrm{Bu}$ yüzden piyasalardaki volatilite finansal piyasalarda işlem yapan tüm paydaşlar yani yatırımcı, finansal uygulayıcı ve karar mekanizmaları tarafından takip edilmek zorunda kalınmıştır. Volatiliteyi ölçmek için birçok endeks mevcuttur ama en önemli ve herkes tarafından benimsenen göstergelerden biri Chicago Opsiyon Borsası tarafından hesaplanan VIX (Volatility Index) endeksi olmaktadır.

Çalışmanın amacı korku endeksi olarak ifade edilen VIX endeksinin Türkiye uluslararası yatırım pozisyonunun (UYP) varlıklar ve yükümlülükler kalemlerinin üzerinde etkili olup olmadığını incelemektir. Çalışmamız diğer çalışmalardan farklı olarak VIX endeksinin sadece borsa endeksleri ve birkaç temel gösterge üzerindeki etkisine odaklanmayıp bütüncül bir yaklaşımla UYP kalemleri üzerinde etkisi araştırılmıştır. VIX endeksinin UYP üzerinde etkisini hem kısa vadeli hem de uzun vadeli etkileyip etkilemediğini belirlemek aynı zamanda kalıcı bir nedenselliğe yol açıp açmadığını tespit etmeye amaçlanmıştır. Aşağıda, şekil 1 de 2006 - 2019 yılları arasındaki uluslararası yatırım pozisyonu varlıklar, yükümlülükler kalemleri ile VIX endeksinin tarihsel gelişimi gösterilmiştir.

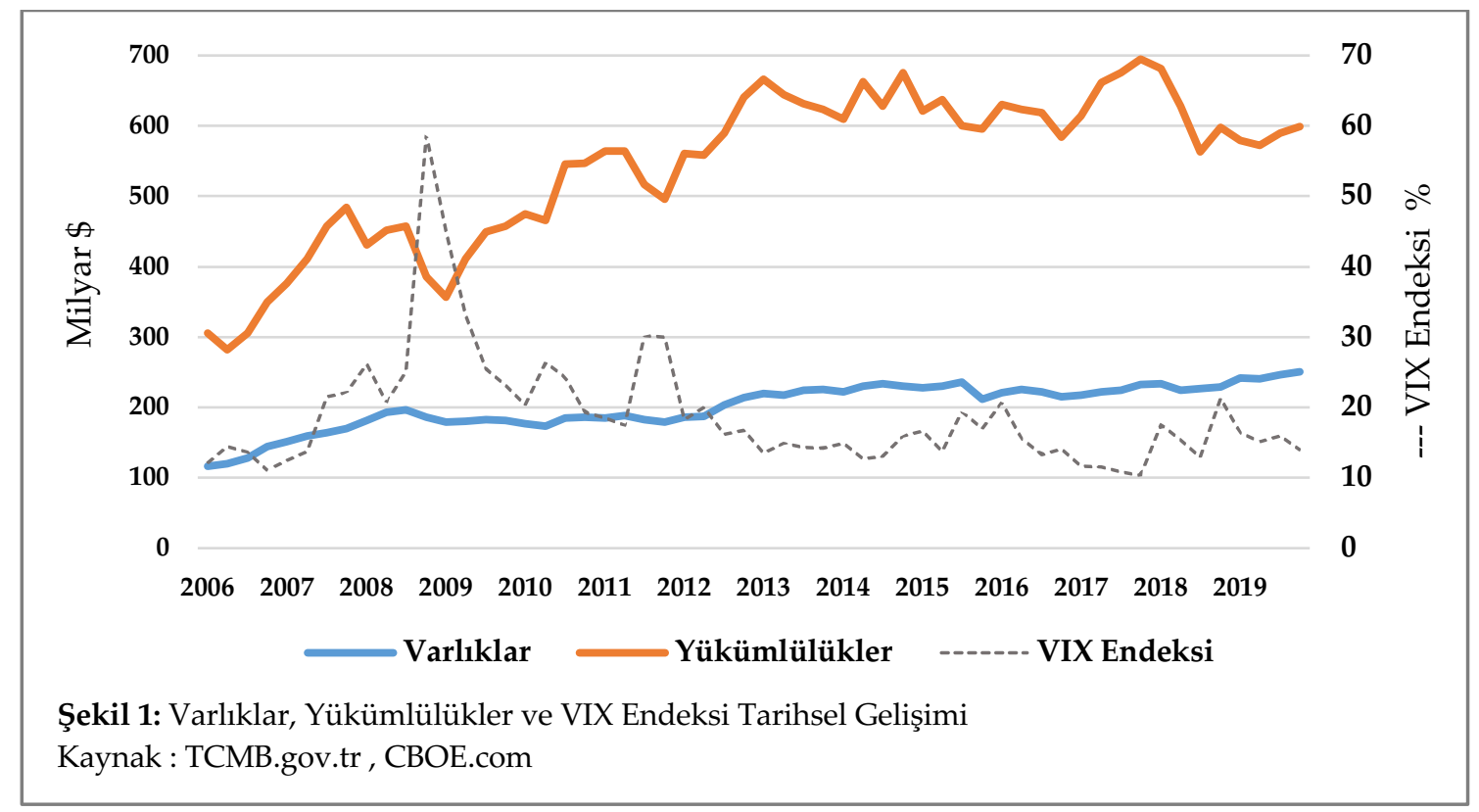

Bilindiği kadarıyla Rey (2013) VIX endeksi ile likidite arasındaki ilişkiyi açıklamasına rağmen literatürde VIX endeksi ile uluslararası yatırım pozisyonunun varlıklar ve yükümlülükler 
kalemlerinin arasındaki ilişkiyi inceleyen bir çalışmaya rastlanmamıştır. Bu açıdan mevcut çalışma VIX ve varlıklar ve yükümlülükler kalemlerinin ilk defa ele alınması ve aralarında nedensellik ve uzun dönemli ilişkisinin olup olmadığının tespiti açısından özgünlük taşımaktadır.

Çalışma beş bölümden oluşmaktadır. İlk bölümde konuya temel bir giriş yapılarak VIX korku endeksi ile UYP tablosu, varlık ve yükümlülük kalemleri hakkında bilgiler verilmiş, ikinci bölümde VIX korku endeksi ile çeşitli finansal göstergeler ve borsa endeksleri arasındaki ilişki ile ilgili literatür incelemesine yer verilmiş, üçüncü bölümde çalışmada kullanılan veri ve uygulanacak yöntemler ve çalışmadan elde edilen bulgular hakkında bilgi verilmiş, son bölümde ise genel bir değerlendirme yapılarak sonuçlar yorumlanmıştır.

\section{VIX ENDEKSI}

Literatürde kullanılan yatırımcı riskinden kaçınma konusundaki en yaygın gösterge, $\mathrm{ABD}$ zımni sermaye dalgalanması yani VIX endeksi olmaktadır. Bizde araştırmamızda bu endeksi kullanarak UYP nasıl etkilendiği araştırmaya çalışacağız. VIX, küresel finansal döngü ile yakın ilişkisi göz önüne alındığında son yıllarda özel bir odaklanmaya başlamıştır (Rey, 2013). 1993 yılında Chicago Borsası tarafından bir volatilite endeksi kurularak, piyasalardaki volatilitenin takip edilmesi amaçlanmışır. Chicago Board Options Exchange (CBOE) tarafından yaratılan, Volatility Index veya VIX, S\&P 500 endeksini temel alan, 22 gün vadeli alım-satım opsiyonlarının oynaklıklarından meydana getirilen ve kısitlayıcı opsiyon fiyatlandırma modeline atıfta bulunulmadan türetilmiş bir zımni volatilite endeksidir (Becker, Clements ve McClelland, 2009: 1034). Başlangıçta S\&P 100 endeksi esas alınarak hesaplanmakta iken, Eylül 2003'ten itibaren S\&P 500 endeksi esas alınarak hesaplanmaktadır (Ozair, 2014: 83). Yatırımcılar, araştırma analistleri ve portföy yöneticileri, VIX değerlerini, yatırım kararlarını almadan önce piyasa riskini, korkusunu ve stresini ölçmenin bir yolu olarak görmektedirler. VIX, “yatırımcı korku göstergesi” olarak adlandırılmıştır. Oynaklık, teknik olarak beklenmedik yukarı veya aşağı yönlü hareketler demek olsa da, S\&P 500 endeksi opsiyon piyasası, borsadaki potansiyel düşüşten endişe ettikleri zaman endeks kotasyonları satın alarak korunmak (hedgers) isteyenlerin hakim olduğu piyasadır. VIX endeksi gerçekte, portföy sigortasının fiyatını yansıtan bir göstergedir (Whaley, 2009: 101).

Endeksin yükselmesi, piyasadaki volatilite beklentisinin de yükseleceğini, endeksin düşmesi piyasadaki volatilite beklentisinin de düşeceğini ifade etmektedir. Genel olarak VIX endeksinin \%30'un üzerine çıkması, yatırımcıların risk algılarının arttığını ve gelecekteki beklentilerin kötüleştiğini gösterirken, endeksin \%20'nin altında kalması yatırımcıların risk algısının azaldığını göstermektedir (Kaya vd., 2014: 2). VIX endeksi, piyasalardaki korkuyu yansitmakta, finansal kırılganlık açısından önem taşımakta ve krizlerin öncüsü olarak görülmektedir (Kaya, 2015: 5). VIX Endeksinin belki de en değerli özelliklerinden biri, 25 yıldan fazla tarihsel fiyatın varlığıdır. Bu kapsamlı veri seti, yatırımcılara çeşitli piyasa koşullarına tepki olarak opsiyon fiyatlarının nasıl davrandığına ilişkin faydalı bir bakış açısı sağlamaktadır.

VIX'in hisse senedi piyasası oynaklık beklentilerini temsil etmesi, konvertibilite kısıtlamaları ve merkez bankası müdahaleleri gibi FX piyasasına özgü çarpıklıklardan etkilenmediği ve bu nedenle ileriye dönük genel risk algısını yansıtmaktadır. Risk algısının artması, tüm piyasalarda ve varlık sınıflarında beklenen oynaklığı artırma eğilimindedir. Bu artış, genellikle sermaye çıkışları ve yüksek döviz kuru oynaklığını gören gelişmekte olan ekonomiler üzerinde orantısız bir etkiye sahiptir. Bu nedenle, piyasa değişkenliği ve risk algılamasının genel bir ölçüsü olan VIX'in UYP varlıklar ve yükümlülükler kalemlerinin üzerinde bir etkisi olabileceğini varsayiyoruz. 


\section{ULUSLARARASI YATIRIM POZISYONU}

Uluslararası Yatırım Pozisyonu (UYP), bir ekonomideki yerleşik kişilerin yurtdışı yerleşik kişilerden olan finansal alacakları ile rezerv varlık olarak tutulan altın şeklindeki finansal varlıklarının ve yerleşiklerin ${ }^{1}$ yurtdışı yerleşik kişilere olan finansal yükümlülüklerinin belli bir tarihteki stok değerini gösteren istatistiki bir tablodur (UYP, 2014:2).

UYP bir ekonomide yerleşiklerin, yerleşik olmayanlardan finansal alacakları ile rezerv olarak tutulan altın ve bir ekonomide yerleşiklerin, yerleşik olmayanlara borcu şeklinde tanımlanmıştır (BPM6, 2009:119).

Uluslararası Yatırım Pozisyonu istatistikleri, Uluslararası Para Fonu (IMF) tarafından üye ülkelere yol gösterici olarak hazırlanan el kitabında ${ }^{2}$ yer alan uluslararası standartlar temelinde derlenmektedir. Söz konusu standartlar, uluslararası yatırım pozisyonu istatistiklerinin tutarlı, karşılaştırılabilir ve güvenilir bir şekilde derlenmesini sağlamaktadır (Uluslararası Yatırım Pozisyonu İstatistiklerine İlişkin Yöntemsel Açıklama, 2018:8). UYP, bir ekonomi ile dünyanın geri kalanı arasındaki işlem ve pozisyonlara ilişkin istatistikler için standart bir çerçeve görevi görmektedir (BPM6, 2009:1).

Türkiye'nin yurtdışı varlık ve yükümlülüklerinin belli bir tarih itibarıyla stok değerini gösteren UYP, 1996 yılından itibaren derlenmeye başlanmıştır. 2000 yılında varlık ve yükümlülük kalemlerine doğrudan yatırım ve 2001 yılında varlık kalemine Türkiye'nin yurtdışı portföy yatırım stok rakamlarının eklenmesi ile çeyrek dönemler itibarıyla ve gösterge niteliğinde aylık olarak yayımlanmaktadır ("Uluslararası Yatırım Pozisyonu İstatistikleri” ne İlişkin Yöntemsel Açıklama, 2018:16). TCMB 6. el kitabına yönelik ödemeler dengesi istatistiklerini 2014 yılının son çeyreğinde yayınlamaya başlamıştır (TCMB, 2014:3).

IMF 6. El Kitabına göre düzenlenen uluslararası yatırım pozisyonu; varlıklar ve yükümlülükler olarak iki ana gruptan oluşmaktadır. Uluslararası yatırım pozisyonu tıpkı bir bilanço gibi iki taraflı bir tablo biçiminde düzenlenir. Tablonun bir tarafında varlıklar diğer tarafında yükümlülükler yer alır.

\section{LITERATÜR ARAŞTIRMASI}

VIX endeksinin finansal piyasalar üzerindeki etkisine yönelik literatürde yer alan çalışmalara bakıldığında çalı̧̧maların birçoğunun ülkelerin borsa endeksleri üzerine yapıldığı görülmektedir.

Çalışmamızda Milesi-Ferretti ve Tille (2011), Forbes ve Warnock (2012) ve Ghosh ve ark. (2014) çalışmalarıyla tutarlıdır. Buna göre finansal piyasalardaki küresel riskteki artışın yabancı yatırımcıları, yatırımlarını azaltmaya yönlendirdiğini beklemekteyiz. Küresel finansal dalgalanmalar olduğunda yabancı yatırımcıların nakit bakiyelerine daha fazla dikkat ettikleri ve piyasaların istikrarını beklemeyi tercih ettikleri bilinmektedir.

Aşağıda VIX endeksi ile ilgili yapılmış çalışmalar özetlenmiştir.

\footnotetext{
${ }_{1}^{1}$ Yerleşikler bir ekonomide bir yıldan fazla sure ile devamlı ve düzenli olarak ikamet eden, o ekonomi içerisinde faaliyette olan kurum ve kişilerdir ve tanım dışındakiler ise yerleşik olmayanlar olarak tanımlanırlar (TCMB).
}

2 Ödemeler Dengesi ve Uluslararası Yatırım Pozisyonu Altıncı El Kitabı (BPM6) 
Arbatlı (2011), 46 gelişmekte olan ülkeye 1990-2009 dönemi verilerini kullanarak doğrudan yabancı sermaye yatırımlarının belirleyicilerini incelemeye çalışmıştır. Ulaştı̆̆ 1 sonuçlara göre küresel riskten kaçınma ve belirsizlik faktörlerinin doğrudan yabancı sermaye yatırımlarını önemli bir şekilde etkilediği görülmüştür. Aynı zamanda doğrudan yabancı sermaye yatırımları ile VIX Endeksi arasındaki korelasyonun düşük olurken, 2006 yılı sonrası gibi bazı dönemlerde, aralarında anlamlı bir negatif ilişki gözlemlenmiştir.

Herrmann ve Mihaljek (2013), gelişmiş ülkelerden gelişmekte olan ülke ekonomilerine banka kredileri akışlarındaki yayılma etkilerinin doğasını incelemeye çalışışlar. 1993-2008 yılları arasında Asya, Latin Amerika, orta ve doğu Avrupa'daki 17 gelişmiş ila 28 gelişmekte olan piyasa ekonomisi arasındaki sınır ötesi banka akışları üzerine bir panel verisi kurmuşlar. Elde edilen bulgulara göre küresel riskten kaçınma ve beklenen finansal piyasa dalgalanması, 2007-08 krizi sırasında sınır ötesi banka kredi akışlarındaki azalmanın arkasındaki en önemli faktörlerden biri olmaktadır. Orta ve doğu Avrupa'ya verilen sınır ötesi kredilerdeki azalma, büyük ölçüde Avrupa'daki finansal ve parasal entegrasyon derecesi ve bölgedeki nispeten sağlam bankacilık sistemleri nedeniyle Asya ve Latin Amerika'ya kıyasla daha sınırlı bir şekilde gerçekleşmiştir.

Rey (2013), araştırma konusu olarak VIX endeksi ile çeşitli göstergelere değinmiştir. Sonuçlara göre "Carry Trade" akışlarının VIX düşük olduğunda artma eğiliminde olurken, VIX endeksinin ani yükseldiğinde çökme eğiliminde olduğunu göstermektedir. Ayrıca VIX endeksi doğrudan yabancı sermaye girişleri hariç olmak üzere diğer sermaye girişlerindeki dalgalanmalarla önemli ölçüde ilişkilidir. Ayni zamanda VIX endeksindeki bir düşüş, sınır ötesi kredi akışlarında artışa neden olurken, VIX'deki artış küresel iç kredide düşüşe yol açtığı görülmüştür.

Concer ve Kassab (2014), yaptıkları çalışmada Brezilya için dışa doğrudan yabancı yatırım akışlarının (OFDI) ${ }^{3}$ temel etkenlerini (VIX, FAİZ, TİCARET hacmi) belirlemek için öncelikle VAR (vektör otomatik regresyonu) modeli kullanıp daha sonra değişkenleri Granger nedensellik açısından test etmişler. Varılan bulgulara göre VIX ve FAİZ ile OFDI arasındaki korelasyonlar istatistiksel olarak anlamlı değildir. Değişkenler arasında sadece TICARET için Granger nedensellik etkisi gösterilmiştir.

BIST 100 endeksi ile VIX endeksi arasındaki nedensellik ilişkisini Kaya (2015), çalışma konusu yapmıştır. 02/01/2009-11/01/2013 dönemini kapsayan çalışmada, Johansen-Jeselius eşbütünleşme testi ve vektör hata düzeltme modeli uygulanmıştır. Johansen-Juselius eşbütünleşme testi sonuçları BIST 100 endeksi ile VIX endeksi arasında eş-bütünleşme olduğunu, hata düzeltme modeli ise BIST 100 endeksinin VIX endeksinden etkilendiğine işaret etmektedir.

Ibarra vd. (2019), vektör otoregresif modeli yardımıyla 1995 - 2015 yılları arasında Ödemeler Dengesi finansal hesabın her bir bileşenindeki şokların küresel risk göstergesi olarak VIX endeksinden etkilendiği ve kalıcılığını, Meksika kamu ve özel sektör menkul kıymetlerinin yanı sıra yerleşiklerin yabancı menkul kıymetlere yatırımını araştırmışlar. Varılan sonuçlara göre küresel riskteki artış, özellikle özel sektör menkul kıymetlerinde daha düşük portföy yatırımını sağlamaktadır. Yabancı yatıımcılar, yerli yatırımcılara kıyasla dış faiz ve likidite şoklarına daha fazla tepki verdiği görülmüştür.

Koepke (2019), Küresel riskten kaçınma ve gelişmiş ekonomi faiz oranları gibi konjonktürel faktörlerinin portföy yatırımı ve borç akışları için en önemli etken olduğu bulmuştur. Bankacılık akışlarına ilişkin kanıtlar, hem dış etkenler (riskten kaçınma ve daha az ölçüde yabancı faiz oranları) hem de ülkeye özgü faktörler (yurt içi büyüme, ülke kırılganlığı göstergeleri ve yurtiçi aktif getirileri) önemli bir rol oynadığını kanaatine varmıştır.

\footnotetext{
${ }^{3}$ Outward Foreign Direct Investment
} 


\section{EKONOMETRIKK ANALIZ}

\section{Veri Seti}

$\mathrm{Bu}$ çalışma, VIX Endeksi'nin uluslararası yatırım pozisyonunun varlıklar ve yükümlülükler kalemlerinin üzerinde olan etkisini araştırmaktadır. Bu amaçla IMF altıncı el kitabının yayımından sonra ilk verileri yani 2006 birinci çeyrek baz alınarak çeyreklik veriler üzerinden analizler yapılmıştır. UYP tablosuna ait veriler TCMB veri tabanından temin edilmiş iken; VIX Endeksi'ne ait verilere ise CBOE Chicago Borsası veri tabanından ulaşılmıştır. Ayrıca söz konusu veriler doğal logaritmaları alınarak çalışmaya dahil edilmiştir. Ampirik bulgular EViews 10 ekonometri paket programı yardımıyla elde edilmiştir.

$\mathrm{Bu}$ çalışmada, VIX endeksi ile uluslararası yatırım pozisyonu varlıklar ve yükümlülükler kalemlerinin arasındaki ilişki inceleneceğinden, bu bölümde söz konusu amaca ulaşabilmek için gerçekleştirilmesi gereken birim kök, eşbütünleşme, hata düzeltme ve nedensellik testleri açıklanmıştır.

Araştırmada iki model kullanılmıştır.

$$
\begin{aligned}
& V A R=\alpha_{0}+\alpha_{1} V I X+\varepsilon_{1 t} \\
& Y U K=\beta_{0}+\beta_{1} V I X+\varepsilon_{2 t}
\end{aligned}
$$

Çalışmada UYP tablosunun varlıklar kalemi (VAR), yükümlülükler kalemi (YUK) ve VIX endeksi (VIX) değişkenleri kullanılarak gösterilmiştir. Kullanılan veriler doğrusal hale gelebilmesi için değişkenlerin doğal logaritmaları alınarak analizlerde kullanılmıştır. Çalışmanın ilk aşamasında serilerin tanımlayıcı istatistikleri ele alınmıştır. 2006 - 2019 arası dönemi kapsayan verilerin kullanıldığı çalışmaya ait tanımlayıcı istatistikler aşağıdaki Tablo 1'de yer almaktadır.

Tablo 1: Serilerin Tanımlayıcı İstatistikleri

\begin{tabular}{|l|c|c|c|}
\cline { 2 - 4 } \multicolumn{1}{c|}{} & Log VIX & Log VAR & Log YUK \\
\hline Ortalama & 2.865322 & 12.19750 & 13.18193 \\
\hline Medyan & 2.791442 & 12.26790 & 13.26352 \\
\hline Maksimum & 4.073121 & 12.43161 & 13.45144 \\
\hline Minimum & 2.333114 & 11.66447 & 12.54922 \\
\hline Std. Sapma & 0.348142 & 0.176587 & 0.224967 \\
\hline Çarpıklık & 1.153371 & -1.171252 & -1.115705 \\
\hline Basıklık & 4.653606 & 4.137582 & 3.427077 \\
\hline Jarque-Bera & 18.79610 & 15.82332 & 12.04371 \\
\hline Olasılık & 0.000083 & 0.000366 & 0.002425 \\
\hline
\end{tabular}

Normallik testti sonuçlarına göre Jarque-Bera istatistiğinin olasılık değeri $0.05<0.85$ olduğundan H0 hipotezi reddedilemez. Jarque Bera testinin H0: Hipotezi "Hata terimi normal dağılmaktadır" biçiminde oluşturulduğundan, hata teriminin normal dağılım koşulunu sağladığı sonucuna ulaşılmıştır.

\section{Birim Kök Testleri}

Çalışmanın ARDL analizi için uygun olup olmadığına karar vermenin birinci aşaması değişkenlere ait durağanlık analizinin yapılmasıdır. Birim kök testleri, ekonometrik analizlerde önemli bir durum olan serilerin durağanlı̆̆ının sınanmasında sıkça uygulanan bir yöntem 
türüdür. Serilerin durağan olması, serilerin sabit bir ortalama ve varyansa sahip olduğunu ve zaman geçtikçe belli bir değere yaklaştığını ifade etmektedir.

Durağan olmayan zaman serileri kullanıp regresyon analiziyle elde edilen sonuç gerçek ilişkiyi yansıtmayabilecektir. Bununla birlikte durağan olmayan zaman serileriyle yapılan regresyon analizleri, sadece bu seriler arasında bir eşbütünleşme ilişkisi varsa gerçek ilişkiyi yansıtabilir. Bu yüzden ekonomi ve finans alanında model tahminine geçmeden önce araştırmada kullanılacak veri setlerine ilişkin serilerin durağan hale getirilmesi gerekmektedir (Gujarati, 1999: 726).

$\mathrm{Bu}$ amaçla, çalışmada ilk önce üzerinde çalışılan verilerin durağan olup olmadıkları test edilmiştir. Verilerin durağanlık analizleri literatürde yaygınca kullanılan hem geleneksel birim kök testlerine göre, hem de yapısal kırılmaya izin veren birim kök testlerine göre analiz edilmiştir. Geleneksel birim kök testlerine olarak Genelleştirilmiş Dickey Fuller (ADF) ve Phillips-Perron (PP) testleri kullanılırken, yapısal kırılmaya izin veren birim kök testi olarak Zivot ve Andrews birim kök testi ile analiz gerçekleştirilmiştir. Birim kok testlerinde elde edilen sonuçlar tablo 2 ve 3 'de gösterilmiştir.

Tablo 2: ADF ve PP Birim Kök Testi Sonuçları

\begin{tabular}{|c|c|c|c|c|c|}
\hline \multirow{2}{*}{ Değişken } & \multicolumn{2}{|c|}{ ADF Testi } & \multicolumn{2}{|c|}{ Phillps - Perron Testi } & \multirow{2}{*}{ Sonuç } \\
\hline & Sabitli & Sabitli ve Trendli & Sabitli & Sabitli ve Trendli & \\
\hline Ln VIX & $\begin{array}{c}-2.834858 \\
(0.0600) \\
\end{array}$ & $\begin{array}{c}-3.351643 \\
(0.0688) \\
\end{array}$ & $\begin{array}{c}-2.810806 \\
(0.0633) \\
\end{array}$ & $\begin{array}{c}-3.336923 \\
(0.0710) \\
\end{array}$ & $\mathrm{I}(0)$ \\
\hline Ln VAR & $\begin{array}{c}-3.550701 \\
(0.0101) \\
\end{array}$ & $\begin{array}{c}-3.607814 \\
(0.0383) \\
\end{array}$ & $\begin{array}{c}-3.433275 \\
(0.0139) \\
\end{array}$ & $\begin{array}{c}-3.607814 \\
(0.0383) \\
\end{array}$ & $\mathrm{I}(0)$ \\
\hline Ln YUK & $\begin{array}{c}-2.515009 \\
(0.1175) \\
\end{array}$ & $\begin{array}{c}-2.201166 \\
(0.4794) \\
\end{array}$ & $\begin{array}{c}-2.537060 \\
(0.1125) \\
\end{array}$ & $\begin{array}{c}-2.208796 \\
(0.4753) \\
\end{array}$ & - \\
\hline$\Delta$ Ln YUK & $\begin{array}{c}-6.851401 \\
(0.0000)\end{array}$ & $\begin{array}{c}-7.215144 \\
(0.0000)\end{array}$ & $\begin{array}{c}-6.851401 \\
(0.0000)\end{array}$ & $\begin{array}{c}-7.217648 \\
(0.0000)\end{array}$ & $\mathrm{I}(1)$ \\
\hline
\end{tabular}

Tablo 3: Zivot ve Andrews Kırılmalı Birim Kök Testi Sonuçları

\begin{tabular}{|c|c|c|c|c|c|}
\hline Değişken & Model & Gecikme & $\begin{array}{l}\text { Kirılma } \\
\text { Tarihleri }\end{array}$ & Test İstatistiği & P Değeri \\
\hline \multirow{2}{*}{ Ln VIX } & A & 0 & 2012Q1 & -3.985002 & 0.016085 \\
\hline & $\mathrm{C}$ & 0 & 2009Q2 & -4.947002 & 0.003285 \\
\hline \multirow{2}{*}{ Ln VAR } & A & 0 & 2012Q2 & -4.239283 & 0.000249 \\
\hline & C & 0 & $2015 Q 4$ & -3.686109 & 0.019701 \\
\hline \multirow{2}{*}{ Ln YUK } & A & 0 & 2009Q2 & -3.248445 & 0.000173 \\
\hline & C & 0 & 2007Q1 & -3.560969 & 0.168809 \\
\hline
\end{tabular}

Sonuçlara göre VIX ve varlıklar seviyede durağandırlar. Yükümlülükler serisi ise düzeyde durağan değildir, birinci farkı alındığı zaman durağan hale gelmektedir.

\section{ARDL Eşbütünleşme Testi}

Çalışmada analize konu olan seriler (Varlıklar, Yükümlülükler ve VIX) farklı düzeylerde durağan olarak tespit edilmişlerdir. Değişkenler arasında uzun dönemli ilişkinin tespit edilmesi için 
kullanılan klasik eşbütünleşme testlerinin (Engle-Granger; Johansen) aynı dereceden durağan olmaları koşulu tüm veri setlerinde sağlanamaması, araştırmacılar için bir sorun teşkil etmekteydi. Buna yönelik olarak Pesaran vd. 1996 yılında ARDL modelini önermişlerdir. Daha sonra 1997, 1998, 1999 ve 2001 yıllarında Pesaran vd. tarafından yapılan çalışmalar ile geliştirilen bu model, klasik eşbütünleşme testlerinin aksine, serilerin hangi düzeyde durağan olduklarına bakılmaksızın, incelenen veri setleri arasında bir eşbütünleşme olup olmadığg tespit edilmeye çalışılmaktadır.

ARDL analizinde ilk adım değişkenler arasında uzun dönemli bir ilişkinin olup olmadığını araştırmak için ARDL sınır testinin yapılmasıdır. Sınır testinin uygulanabilmesi için öncelikle kısıtsız hata düzeltme modelinin kurulması gerekmektedir.

Pesaran vd., (2001) çalışmalarına göre yapılan sınır testi sonucunda $\mathrm{F}$ istatistik değeri, \%5 anlamlılık düzeyindeki üst kritik değerin üzerinde olduğu zaman değişkenler arasında uzun dönemli bir ilişki varken, alt kritik değerin altında olduğu zaman değişkenler arasında uzun dönemli bir ilişki olmayıp, F istatistik değeri alt ve üst kritik değer arasındaki aralıkta bulunduğu zaman ise kararsız bölgede olduğuna karar verilmektedir. 1 ve 2 numaralı denklemlere göre uyarlanmış bu model, 3 ve 4'nolu denklemlerdeki gibi gösterilebilir.

$$
\begin{aligned}
& \Delta V A R=\alpha_{0}+\sum_{i=1}^{n} \alpha_{1 i} \Delta V A R_{t-i}+\sum_{i=0}^{n} \alpha_{2 i} \Delta V I X_{t-i}+\alpha_{3} V A R_{t-1}+\alpha_{4} V I X_{t-1}+\varepsilon_{1 t} \\
& \Delta Y U K=\beta_{0}+\sum_{j=1}^{m} \beta_{1 j} \Delta Y U K_{t-j}+\sum_{j=0}^{m} \beta_{2 j} \Delta V I X_{t-j}+\beta_{3} Y U K_{t-1}+\beta_{4} V I X_{t-1}+\varepsilon_{2 t}
\end{aligned}
$$

Yukarıdaki modellerde sınır testinin uygulanabilmesi için uygun gecikme uzunluğunun belirlenmesi gerekmektedir. Gecikme uzunluğunun belirlenmesi için AIC (Akaike information criterion), SC (Schwarz information criterion) FPE (Final prediction error) ve HQ (Hannan-Quinn information criterion) gibi bilgi kriterlerinden yararlanılmaktadır. Uygun gecikme uzunluğu 1 olarak belirlenmiştir. ARDL sınır testi sonuçları tablo 4'de gösterilmiştir.

Tablo 4: ARDL Sınır Testi

\begin{tabular}{|c|c|c|c|c||}
\hline Model & k & F istatistik & Alt Sınır I(0) \%1 & Üst Sınır I(1) \%1 \\
\hline 3 - VAR & 1 & 12.87437 & 4.94 & 5.58 \\
\hline 4 - YUK & 1 & 6.006688 & 4.94 & 5.58 \\
\hline
\end{tabular}

Varılan sonuçlara göre denklem 3 için F istatistiği değeri 12.87437 iken, denklem 4 için 6.006688 olmaktadır. Her iki denklem için $\mathrm{F}$ istatistiği değeri kritik değerin üzerinde olduğundan dolayı her iki denklem için uzun dönem ilişkisinin varlı̆̆ını tespit etmekteyiz.

Değişkenler arasında uzun dönemli ilişki tespit edildikten sonra ARDL eş bütünleşme analizi yapılarak değişkenlere ait katsayı tahmin edilmektedir. Uzun dönem katsayılarının tahmini için 1 ve 2'nolu denklemlere istinaden ARDL modelleri kurulmuştur.

$$
\begin{aligned}
& V A R=\alpha_{0}+\sum_{i=1}^{n} \alpha_{1} V A R_{t-i}+\sum_{i=0}^{n} \alpha_{2} V I X_{t-i}+\varepsilon_{1 t} \\
& Y U K=\beta_{0}+\sum_{j=1}^{m} \beta_{1} Y U K_{t-j}+\sum_{j=0}^{m} \beta_{2} V I X_{t-j}+\varepsilon_{2 t}
\end{aligned}
$$


Modeller kurulduktan sonra analize geçmenin ilk adımı gecikme uzunluğunun belirlenmesidir. Gecikme uzunluğunun belirlenmesinde Akaike bilgi kriterinden yararlanılmıştır. Şekil 2 de görüldüğü gibi her iki modelimiz için uygun gecikme uzunluğu $(1,0)$ olarak gerçekleşmektedir.
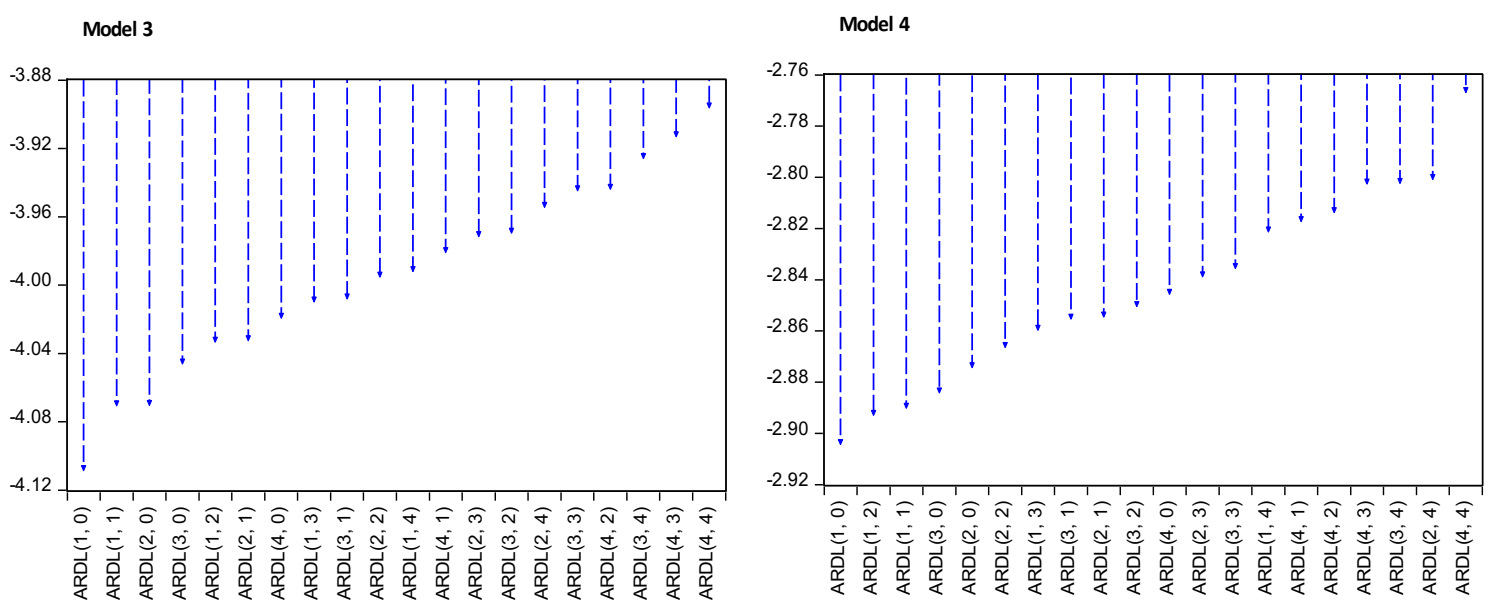

Şekil 2: ARDL Uygun gecikme uzunluğu

Uygun gecikmenin belirlenmesinden sonra ARDL sonuçları Tablo 5 ve 6 de gösterilmiştir.

Tablo 5: Model 5 Uzun Dönem ARDL $(1,0)$ tahmin sonuçları

\begin{tabular}{|l|c|c|c||}
\hline \multirow{2}{*}{ Değişken } & \multicolumn{3}{|c|}{ Bağımlı Değişken: VAR } \\
\cline { 2 - 4 } LOGVAR (-1) & Katsayı & Std. Hata & T istatistiği \\
\hline LOGVIX & 0.892536 & 0.024147 & $\begin{array}{c}36.96235 \\
(0.0000)\end{array}$ \\
\hline C & -0.042167 & 0.012178 & $\begin{array}{c}-3.462401 \\
(0.0011)\end{array}$ \\
\hline \hline R $^{2}$ & 1.445388 & 0.302588 & $\begin{array}{c}4.776755 \\
(0.0000)\end{array}$ \\
\hline Düzeltilmiş R & 0.965809 & F İstatistiği & 734.4361 \\
\hline
\end{tabular}

Tablo 6: Model 6 Uzun Dönem ARDL $(1,0)$ tahmin sonuçları

\begin{tabular}{|l|c|c|c||}
\hline \multirow{2}{*}{ Değişken } & \multicolumn{3}{|c|}{ Bağımlı Değişken: YUK } \\
\cline { 2 - 4 } LOGYUK (-1) & Katsayı & Std. Hata & T istatistiği \\
\hline LOGVIX & 0.863010 & 0.039467 & $\begin{array}{c}21.86687 \\
(0.0000)\end{array}$ \\
\hline C & -0.075683 & 0.025711 & $\begin{array}{c}2.943655 \\
(0.0048)\end{array}$ \\
\hline \hline $\mathbf{R}^{2}$ & 2.035097 & 0.547644 & $\begin{array}{c}3.716093 \\
(0.0005)\end{array}$ \\
\hline Düzeltilmiş $\mathbf{R}^{2}$ & 0.918087 & F İstatistiği & 291.4089 \\
\hline \hline
\end{tabular}

Tablo 4 ve 5, bağımlı değişken olarak varlıklar ve yükümlülükler, bağımsız değişken ise VIX endeksi alındığı durumlar için ARDL uzun dönem sonuçlarını göstermektedir. Varlıklar ve yükümlülükler ile VIX endeksi değişkeni arasında anlamlı bir ilişki tespit edilmiştir. Bu sonuçlara 
göre, VIX endeksinde \%1'lik bir artış, varlıklarda \%4,21 oranında düşüş ile sonuçlanırken, yükümlülükler kaleminde \%7.56 bir düşüşe neden olmaktadır.

Model 5 : Varliklar
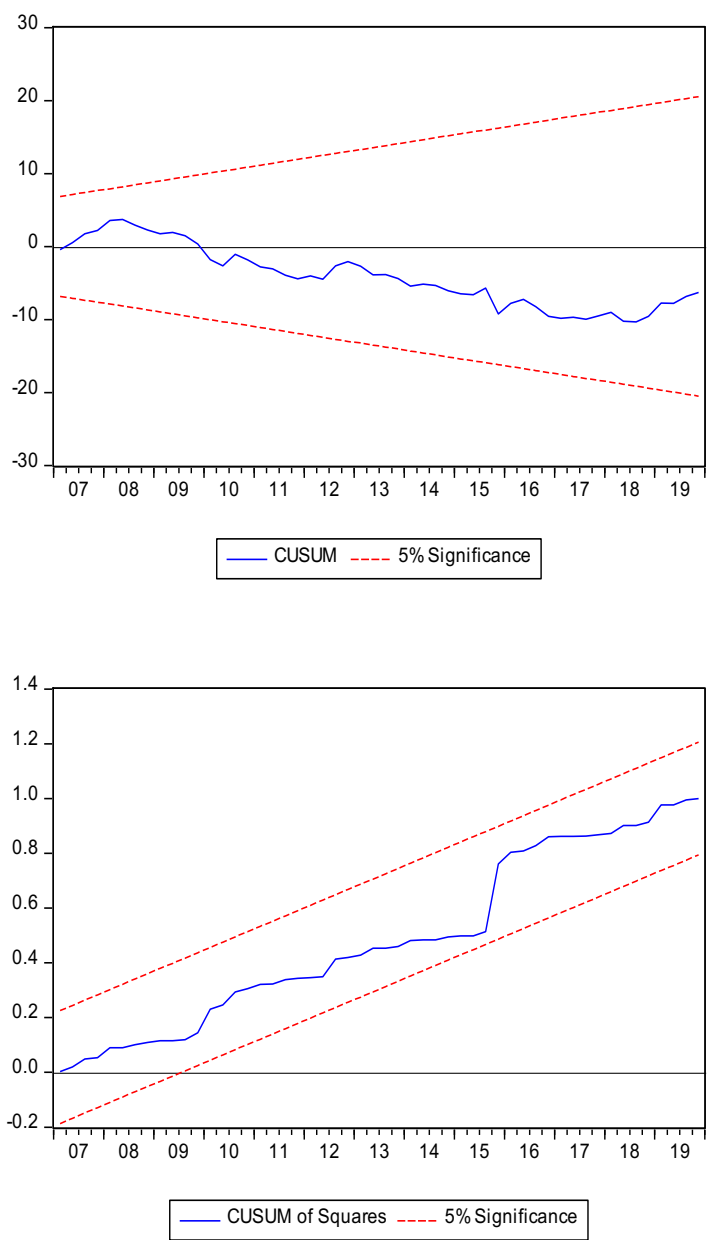

Model 6 : Yükümlülükler
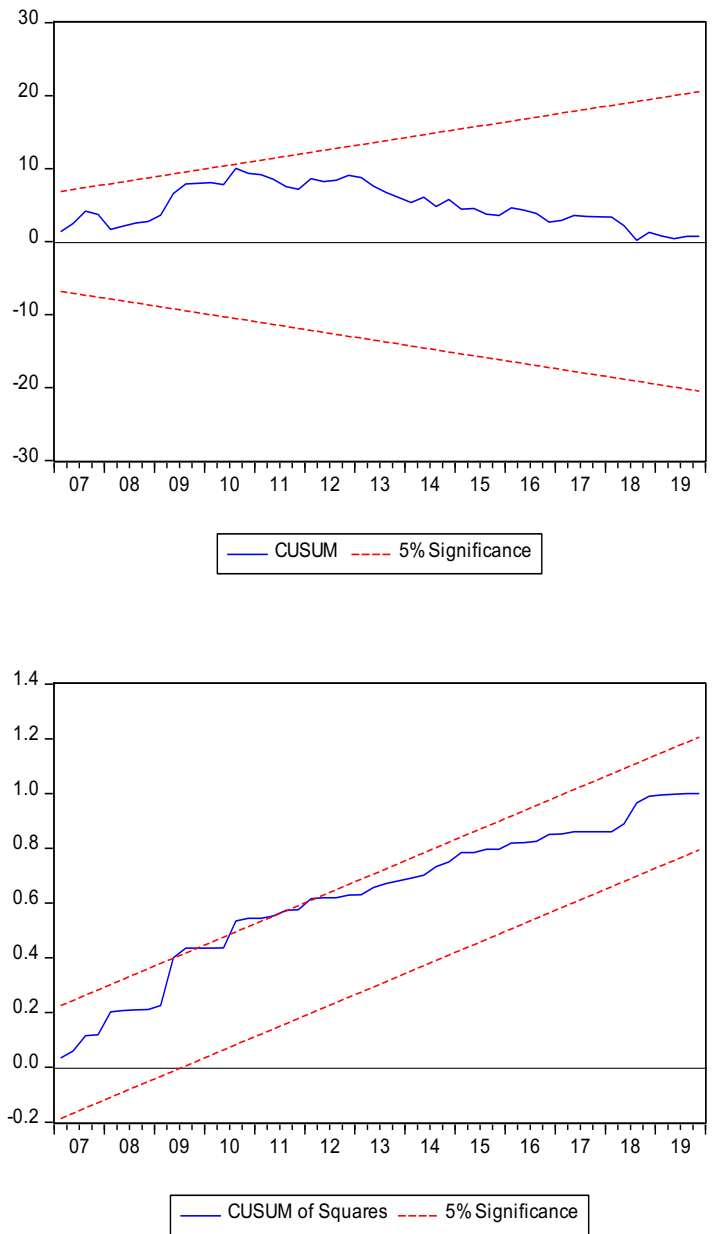

Şekil 3: CUSUM ve CUSUM SQ Grafikleri

Tahmin edilen ARDL modelinin yapısal kırılmaya sahip olup olmadığını araştırmak için şekil 3 de gösterildiği gibi geri dönüşlü hata terimlerinin karelerini kullanan ve bu şekilde değişkenlere ilişkin yapısal kırılmayı araştıran CUSUM ve CUSUMSQ grafiklerinden yararlanılmıştır.

Yukarıdaki CUSUM ve CUSUMSQ grafikleri incelendiğinde, Model 3 yani varlıklar için analiz kapsamında kullanılan VIX değişkenine ilişkin herhangi bir yapısal kırılmanın olmadığını, ARDL Sınır Testine göre hesaplanan uzun dönem katsayıların istikrarlı olduğunu sonucuna varılmıştır. Yükümlülükler kalemi yani Model 4 için ise görüldügü gibi yapısal kırılmanın olmadığı, ama CUSUM SQ grafiğinden 2009Q2 - 2012Q1 dönemi arasında kukla değişken yardımıyla hem yapısal değişiklik olup olmadığını, hem de bu değişikliğin sabit terimden mi yoksa eğim teriminden mi kaynaklandığını araştırmamız gerekiyor. Bu yöntemde bir kukla değişken seçilip bu değişken sabit ve eğim katsayıları ile modele konarak istatistiksel anlamlılığına bakılır. 3 farklı modele ait sonuçlar tablo 7 'de gösterilmiştir. 
Tablo 7: Bağımlı Değişken: YUK

Sabit Katsayılı Kukla Değişkenli Model

\begin{tabular}{|l|c|c|c||}
\hline Değişken & Katsayı & Std. Hata & T istatistiği \\
\hline LOGVIX & -5.743138 & 24.85432 & $\begin{array}{c}-0.231072 \\
(0.8195)\end{array}$ \\
\hline KUKLA & 0.161076 & 1.934217 & $\begin{array}{c}0.083277 \\
(0.9344)\end{array}$ \\
\hline C & 32.33569 & 83.75148 & $\begin{array}{c}0.386091 \\
(0.7033)\end{array}$ \\
\hline \hline $\mathbf{R}^{2}$ & 0.972970 & F İstatistiği & 15.42664 \\
\hline Düzeltilmiş R ${ }^{2}$ & 0.909899 & P değeri & 0.001468 \\
\hline
\end{tabular}

Eğilimli Kukla Değişkenli Model

\begin{tabular}{|l|c|c|c||}
\hline Değişken & Katsayı & Std. Hata & T istatistiği \\
\hline LOGVIX*KUKLA & 0.071605 & 0.112151 & $\begin{array}{c}0.638468 \\
(0.5260)\end{array}$ \\
\hline $\mathbf{C}$ & 13.28807 & 0.117819 & $\begin{array}{c}112.7834 \\
(0.0000)\end{array}$ \\
\hline \hline $\mathbf{R}^{2}$ & 0.856114 & F İstatistiği & 71.39953 \\
\hline Düzeltilmiş R & 0.844124 & P değeri & 0.000000 \\
\hline
\end{tabular}

Eğilimli ve Sabit katsayılı Kukla Değişkenli Model

\begin{tabular}{|c|c|c|c|}
\hline Değişken & Katsayı & Std. Hata & T istatistiği \\
\hline LOGVIX*KUKLA & -0.363420 & 1.312706 & $\begin{array}{c}-0.276848 \\
(0.7845)\end{array}$ \\
\hline KUKLA & 1.394035 & 4.085047 & $\begin{array}{c}0.341253 \\
(0.7362) \\
\end{array}$ \\
\hline C & 13.21955 & 0.335680 & $\begin{array}{c}39.38143 \\
(0.0000)\end{array}$ \\
\hline $\mathbf{R}^{2}$ & 0.868121 & F İstatistiği & 36.20503 \\
\hline Düzeltilmiş $\mathbf{R}^{2}$ & 0.844143 & $P$ değeri & 0.000000 \\
\hline
\end{tabular}

Her üç modelde görüldü gibi kukla değişkenimize ait katsayıların hepsi anlamsız ve yapısal kırılma ve değişikliğinin olmadığı tespit edilmiştir.

Değişkenler arasındaki uzun dönem ilişkilerin belirlenmesinden sonraki aşama, hata düzeltme modeli (ECM) kullanılarak kısa dönemli ilişkilerin araştırılmasıdır.

\section{K1sa Dönem Analizi}

Seriler arasındaki kısa dönem ilişkileri, hata düzeltme modeli çerçevesinde analiz edilmiştir. Çalışmada analizin yapılması için serilerin birinci farkı alınmış halleri ve uzun dönem analizlerinden elde edilen hata terimi (Error Correction Term: ECT) serisinin bir dönem gecikmeli değeri $\left(E C T_{t-1}\right)$ kullanılarak gerçekleştirilmiştir. Analizin bu aşamasında kullanılan modeller şu şekildedir: 


$$
\begin{aligned}
& \Delta V A R=\theta_{0}+\sum_{i=1}^{n} \theta_{1} \Delta V A R_{t-i}+\sum_{i=0}^{n} \theta_{2} \Delta V I X_{t-i}+\theta_{3} E C T_{t-1}+\varepsilon_{1 t} \\
& \Delta Y U K=\gamma_{0}+\sum_{j=1}^{m} \gamma_{1} \Delta Y U K_{t-j}+\sum_{j=0}^{m} \gamma_{2} \Delta V I X_{t-j}+\gamma_{3} E C T_{t-1}+\varepsilon_{2 t}
\end{aligned}
$$

Burada yer alan $E C T_{t-1}$; hata düzeltme terimini temsil etmektedir. Modellerin tahmini sonucunda bu terimin katsayısının istatistiksel olarak anlamlı olması, modellerin hata düzeltme mekanizmalarının çalıştığını göstermektedir. Diğer bir ifadeyle uzun dönemde birlikte hareket eden seriler arasında kısa dönemde meydana gelen sapmaların ortadan kalktığını, yani yapılan uzun dönem analizlerinin güvenilir olduğunu göstermektedir (Tarı, 2012: 433-435).

\begin{tabular}{|c|c|c|c|}
\hline \multirow{2}{*}{ Değişken } & \multicolumn{3}{|c|}{ Bağımlı Değişken: VAR } \\
\hline & Katsayı & Std. Hata & $T$ istatistiği \\
\hline$\Delta$ LOGVAR (-1) & 1.015807 & 0.196445 & $\begin{array}{c}5.170962 \\
(0.0000) \\
\end{array}$ \\
\hline$\Delta$ LOGVIX & -0.050680 & 0.017293 & $\begin{array}{c}-2.930748 \\
(0.0051) \\
\end{array}$ \\
\hline$E C T_{t-1}$ & -1.140592 & 0.241937 & $\begin{array}{c}-4.714412 \\
(0.0000)\end{array}$ \\
\hline C & -0.000891 & 0.004985 & $\begin{array}{c}-0.178805 \\
(0.8588) \\
\end{array}$ \\
\hline $\mathbf{R}^{2}$ & 0.377433 & F İstatistiği & 10.10420 \\
\hline Düzeltilmiş $\mathbf{R}^{2}$ & 0.340079 & P değeri & 0.000026 \\
\hline
\end{tabular}

Tablo 8: Model 7 Kısa Dönem ARDL $(1,0)$ Hata Düzeltme Modeli Tahmin Sonuçları

\begin{tabular}{|c|c|c|c|}
\hline \multirow{2}{*}{ Değişken } & \multicolumn{3}{|c|}{ Bağımlı Değişken: YUK } \\
\hline & Katsayı & Std. Hata & $\mathrm{T}$ istatistiği \\
\hline$\Delta$ LOGYUK (-1) & 1.041137 & 0.233229 & $\begin{array}{l}4.464002 \\
(0.0000)\end{array}$ \\
\hline$\Delta$ LOGVIX & -0.132849 & 0.032098 & $\begin{array}{c}-4.138913 \\
(0.0001) \\
\end{array}$ \\
\hline$E C T_{t-1}$ & -1.199433 & 0.264713 & $\begin{array}{c}-4.531073 \\
(0.0000)\end{array}$ \\
\hline C & 0.001206 & 0.008154 & $\begin{array}{c}0.147960 \\
(0.8830) \\
\end{array}$ \\
\hline $\mathbf{R}^{2}$ & 0.383475 & F İstatistiği & 10.36655 \\
\hline Düzeltilmiş $R^{2}$ & 0.346483 & $P$ değeri & 0.000020 \\
\hline
\end{tabular}

Tablo 9: Model 8 Kısa Dönem ARDL $(1,0)$ Hata Düzeltme Modeli tahmin sonuçları

Hata düzeltme modellerinin sonuçlarına göre uzun dönemli katsayılarına paralel olarak kısa dönemde varlıklar ve yükümlülükler ile VIX endeksi arasında anlamlı bir ilişki tespit edilmiştir. Tablo 8 ve 9'de gösterilen kısa dönem dinamiklerine ilişkin sonuçlar, $\triangle$ VAR ile $\Delta$ VAR(-1) ve $\triangle$ YUK ile $\triangle$ YUK(-1) arasında pozitif ve istatistiki bakımdan anlamlı ilişkilerin varlığını ortaya koymaktadır. Varlıklar ve yükümlülükler kalemlerinin dönem değerlerinin tahmin edilmesinde bu değişkenin bir önceki dönem değerlerinin dikkate alınması gerektiğini vurgulamaktadır. 
Tablo 8 ve 9'teki bulgulara göre; Teorik beklentilerle uyumlu biçimde uzun dönemle ayni şekilde VIX endeksi kısa dönemde de varlıklar ve yükümlülükler kalemlerini negatif ve istatistiksel olarak anlamlı düzeyde etkilemiştir.

Hata terimi düzeltme katsayısı -1 ve -2 arasında bir değer aldığı zaman, ekonomik sistemin dalgalanarak dengeye geldiğini ortaya koymaktadır (Narayan and Smyth, 2006: 339). Bu sonuca göre bir önceki dönemde ortaya çıkan dengesizlikler bir sonraki dönemde kısa sürede dengeye gelmektedir. Kısa dönem analizleri farkı alınmış serilerle yapıldığı için belirlilik katsayılarının (R2) düşük çıkması ise normal kabul edilebilir. Hata düzeltme katsayısına ait $P$ değeri 0,00 olarak bulunduğuna göre her iki modelin anlamlı olduğu sonucuna varılmıştır.

\section{Granger Nedensellik Testi}

Regresyon analizi yaparken değişkenler arasında araştırılan bağımlılık ilişkileri, mutlaka bir nedensellik ilişkisi ifade etmez. Başka bir değişle, mutlaka bağımsız değişken $X^{\prime}$ in sebep ve bağımlı değişken Y'nin sonuç olduğu anlamına gelmez. Regresyon analizinde değişkenler arası bağımlılık ilişkisi araştırılırken, bağımlı ve bağımsız değişken ayrımı ile baştan ilişkilerin yönü hakkında bir ön koşul bulunmaktadır. Fakat nedensellik analizinde böyle bir ön koşul olmayıp ilişkilerin yönü araştırılır. Değişkenler arasındaki bağımlılık, mutlaka bir sebep-sonuç yani nedensellik ilişkisi ifade etmez. Nedensellik analizlerinde sebep-sonuç ilişkilerinin yönü araştırılmaktadır (Tarı, 2011: 436).

Nedensellik analizinde çeşitli testler kullanılmaktadır. Bu testler uzun dönemli zaman serilerine uygulanabilmektedir. Bu testlerden literatürde en fazla kullanılan ve uygulamada da kullandığımız Granger Nedensellik Testi olmaktadır. Nedensellik analizi değişkenler arası ilişkinin nedenselliğinin yönüne doğru yapılan bir araştırmadır. Granger (1969) nedensellik testinde serilerin durağan olmaları önem arz etmekle beraber aynı mertebeden durağan olmalarına ise gerek yoktur. Ayrıca Granger testi, örnek büyüklügünden ve verilerin yıllık veya mevsimsel olma durumlarından etkilenir. Bunun yanında ilişkilerdeki gecikmeli değişken sayısı da önemlidir (Tarı, 2014: 437). Granger nedensellik analizinden önce gecikme uzunluğunun belirlenmesi gerekmektedir. Çalışmada uygun gecikme uzunluğu AIC bilgi kriterinin en küçük değerini dikkate alınarak 1 olarak belirlenmiştir. Granger nedensellik test sonuçları tablo $10^{\prime}$ de gösterilmiştir.

Tablo 10: Granger Nedensellik Testi

\begin{tabular}{||c|c|c|c||}
\hline \hline & Chi-sq & df & P Değeri \\
\hline VIX $\rightarrow$ VAR & 4.312879 & 1 & 0.0378 \\
\hline VAR $\rightarrow$ VIX & 0.377177 & 1 & 0.5391 \\
\hline VIX $\rightarrow$ YUK & 0.564894 & 1 & 0.4523 \\
\hline YUK $\rightarrow$ VIX & 0.593255 & 1 & 0.4412 \\
\hline $\begin{array}{l}H_{0}=\text { Nedensellik ilişkisi yoktur } \\
H_{1}=\text { Nedensellik ilişkisi vardır }\end{array}$ \\
\hline \hline
\end{tabular}

Test sonuçlarına göre VIX korku endeksinden varlıklar kalemine $\% 5$ anlamlılık düzeyinde $\mathrm{H}_{0}$ hipotezi ret edilip tek taraflı nedensellik ilişkisine ulaşırken, VIX endeksi ile yükümlülükler arasında $\mathrm{H}_{0}$ hipotezi kabul edilir, değişkenler arasında herhangi bir nedensellik ilişkisi bulunmamaktadır. 


\section{SONUÇLAR ve GENEL DEĞERLENDİRME}

Son yıllarda ödemeler dengesindeki değişmeler ve artan döviz kuru uluslararası yatırım pozisyonunu daha fazla gündeme getirmektedir. UYP tablosunun alt kalemleri yani varlıklar ve yükümlülükler 2008 mali krizinden bu yana özel bir dikkat çeken küresel riskten kaçınma durumundan güçlü bir şekilde etkilendiğine dair güçlü kanıtlar vardır. Ampirik çalışmalar neredeyse evrensel olarak küresel riskten kaçınmadaki artışların bu sermaye akımları bileşenleri üzerindeki güçlü ve istatistiki açıdan önemli bir etkisi bulduğunu göstermektedir.

VIX endeksi, tüm dünyada menkul kıymet piyasalarının gelecekteki beklenen hareketlerinin tahmini için gösterge olarak kullanılan önemli bir endekstir. Endeksin yükselmesi, piyasadaki volatilite beklentisinin de yükseleceğini, endeksin düşmesi piyasadaki volatilite beklentisinin de düşeceğini ifade etmektedir.

$\mathrm{Bu}$ çalışmanın amacı, VIX endeksi ile uluslararası yatırım pozisyonunun varlıklar ve yükümlülükler kalemlerinin arasındaki eşbütünleşme ve nedensellik ilişkilerinin olup olmadığını araştırmaktır. Çeyreklik veriler kullandığımız çalışmamızda değişkenler arasındaki eşbütünleşme ilişkilerinin analizine geçmeden önce serilerin ADF birim kok yoluyla durağan olup olmadıkları araştırılmıştır. Daha sonra ARDL eşbütünleşme testi yardımıyla serilerin arasında uzun dönem ilişkisi araştırılmıştır. Kısa dönem ilişki hata düzeltme modeli ile araştıııldıktan sonra son olarak Granger nedensellik testi kullanarak VIX endeksi ile varlıklar ve yükümlülükler kalemleri arasında nedensellik ilişkisi araştııılmıştır.

Analizlere göre seriler farklı düzeylerde durağan olduğu sonucuna varılmıştır. ADF ve PP test sonuçlarına göre VAR değişkeninin sabitli ve sabitli - trendli varsayımlarda seviyede durağan olurken diğer serilerin birinci derece farklarının durağan olduğu saptanmıştır. Kısa ve uzun dönem analizlere göre VIX endeksi ile UYP tablosunun varlıklar ve yükümlülükler kalemi arasında hem kısa hem uzun dönemde negatif ve anlamlı bir ilişki mevcuttur, yani VIX endeksinde artışlar her iki kalemde düşüşlere neden olmaktadır. VIX endeksi ile beraber piyasalarda korku ve belirsizliğin arttığ 1 için yatırımclar ve karar vericiler tarafından nakit tutmaya yönelme ve yatırım kararlarının ertelemek sonucunda her iki varlıklar ve yükümlülükler kalemlerinde düşüşle sonuçlanmıştır. Granger nedensellik ilişkisi açısından sadece VIX endeksinden varlıklar kalemine doğru anlamlı bir nedensellik ilişki bulunmaktadır. Nedensellik testi sonucunda elde edilen bilgilere göre yatırımcılar ve karar vericiler açısından değerlendiğimiz zaman varlıklar kaleminde VIX endeksi belirleyici bir faktör olurken yükümlülükler kalemi için ayni şeyi söylemek mümkün değildir.

Yapılacak gelecek çalışmalarda, çalışmaya dahil edilmeyen diğer küresel ve ülkelere özgü göstergeler de dahil edilerek, UYP varlıklar ve yükümlülükler kalemleri arasındaki eşbütünleşme ve nedensellik ilişkileri araştırılabilecektir. Yine çalışmaya diğer ülkelerin UYP varlık ve yükümlülük kalemleri da dahil edilerek, VIX endeksinden etkilenme düzeyleri karşılaştırılabilecektir. Araştırmamızda kullandığımız yöntemler yeterli olsa da farklı bakış açısına sahip Toda-Yamamoto ve Frekans Alanı nedensellik testleri gibi diğer yöntemleri kullanarak analizeler katkı sağlanabilmektedir.

\section{KAYNAKÇA}

Arbatli, E. (2011). Economic Policies and FDI Inflows to Emerging Market Economies. IMF Working Papers 11/192, International Monetary Fund.

Balance of Payments and International Investment Position Manual (BPM6) Sixth Edition (2009). International Monetary Fund, Washington, D.C. 
Becker, R., Clements, A. E. and McClelland, A. (2009). The Jump Component of S\&P 500 Volatility and the VIX Index. Journal of Banking \& Finance, 33 (6) 1033-1038.

Concer, R. and Kassab, P. (2014). The Macroeconomic Determinants of Outward Foreign Direct Investment: Evidences From Brazil. Presented at The 4th Copenhagen Conference on 'Emerging Multinationals': Outward Investment from Emerging Economies, Copenhagen, Denmark, 9-10 October 2014.

Dickey, D. And Fuller, W. (1981). Likelihood Ratio Statistics for Autoregressive Time Series with A Unit Root. Econometrica, 49, 1057-72.

Forbes, K J. and Warnock, F E. (2012). Capital Flow Waves: Surges, Stops, Flight, and Retrenchment. Journal of International Economics 88, 235-51.

Ghosh, A R., Qureshi, M S., Kim J. and Zalduendo, J. (2014). "Surges". Journal of International Economics 92, 266-85.

Granger, C. W. (1969). Investigating Causal Relations by Econometric Models and Cross-Spectral Models. Econometrica.

http://www.cboe.com/vix [Erişim Tarihi: 20.02.2020].

https://www.tcmb.gov.tr/wps/wcm/connect/TR/TCMB+TR/Main+Menu/Istatistikler/Odemeler+ Dengesi+ve+Ilgili+Istatistikler/Uluslararasi+Yatirim+Pozisyonu/ [Erişim Tarihi: 20.02.2020].

Ibarra, R. and Tellez-Leon, I. (2019). Are All Types of Capital Flows Driven by The Same Factors? Evidence from Mexico. Empir Econ.

Kaya, E. (2015). Borsa İstanbul (BIST) 100 Endeksi ile Zımni Volatilite (VIX) Endeksi Arasındaki Eş-Bütünleşme ve Granger Nedensellik. KMÜ Sosyal ve Ekonomik Araştırmalar Dergisi, 17 (28), 16.

Koepke R. (2019). What Drives Capital Flows to Emerging Markets? A Survey of The Empirical Litrature. Journal of Economic Surveys, 33(2), 516-540.

Milesi, F., Gian M., and Cédric T. (2011). The great retrenchment: International capital flows during the global financial crisis. Economic Policy 26, 289-346.

Narayan, P. K. and Smyth, R. (2006). What Determines Migration Flows from Low-İncome Countries? An Empirical Investigation of Fiji-U.S Migration 1972-2001. Contemporary Economic Policiy, 24(2):332-342.

Ozair, M. (2014). What does the VIX Actually Measure: An Analysis of the Causation of SPX and VIX. ACRN Journal of Finance and Risk Perspectives, 3 (2), 83-132.

Rey, H (2013). Dilemma not Trilemma: The Global Financial Cycle and Monetary Policy Independence. paper presented at the Jackson Hole Symposium, August 2013.

Türkiye Cumhuriyet Merkez Bankası A.Ş. (2014). Uluslararası Yatırım Pozisyonu Raporu", Aralık 2014

Türkiye Cumhuriyet Merkez Bankası A.Ş. (2018). Uluslararası Yatırım Pozisyonu İstatistikleri 'ne İlişkin Yöntemsel Açılama", 2018.

Whaley, R. E. (2009). The Journal of Portfolio Management Spring, 35 (3), 98-105. 